\title{
Article \\ Heavy Metals and Trace Elements in Human Breast Milk from Industrial/Mining and Agricultural Zones of Southeastern Spain
}

\author{
Miguel Motas ${ }^{1, *(\mathbb{C}}$, Sandra Jiménez ${ }^{1,2}$, José Oliva $^{3}$, Miguel Ángel Cámara ${ }^{3}$ and María Dolores Pérez-Cárceles ${ }^{2}$ (i) \\ 1 Department of Toxicology, Regional Campus of International Excellence "Campus Mare Nostrum", \\ Faculty of Veterinary, Campus of Espinardo, University of Murcia, 30100 Murcia, Spain; sjrejon@hotmail.com \\ 2 Department of Legal and Forensic Medicine, Biomedical Research Institute (IMIB), Regional Campus of \\ International Excellence "Campus Mare Nostrum", Faculty of Medicine, University of Murcia, \\ 30100 Murcia, Spain; mdperez@um.es \\ 3 Department of Agricultural Chemistry, Regional Campus of International Excellence \\ "Campus Mare Nostrum", Faculty of Chemistry, Campus of Espinardo, University of Murcia, \\ 30100 Murcia, Spain; josoliva@um.es (J.O.); mcamara@um.es (M.Á.C.) \\ * Correspondence: motas@um.es
}

check for updates

Citation: Motas, M.; Jiménez, S.; Oliva, J.; Cámara, M.Á.; PérezCárceles, M.D. Heavy Metals and Trace Elements in Human Breast Milk from Industrial/Mining and Agricultural Zones of Southeastern Spain. Int. J. Environ. Res. Public Health 2021, 18, 9289. https:// doi.org/10.3390/ijerph18179289

Academic Editor: Paul B. Tchounwou

Received: 22 July 2021

Accepted: 30 August 2021

Published: 2 September 2021

Publisher's Note: MDPI stays neutral with regard to jurisdictional claims in published maps and institutional affiliations.

Copyright: (c) 2021 by the authors. Licensee MDPI, Basel, Switzerland. This article is an open access article distributed under the terms and conditions of the Creative Commons Attribution (CC BY) license (https:/ / creativecommons.org/licenses/by/ $4.0 /)$.
Abstract: Human breast milk is the most complete foodstuff for infants but can also be a potential source of exposure to toxic chemicals. The aim of this study was to assess the levels of metal pollution in the breast milk of women living in agricultural and industrial/mining areas of the Region of Murcia (Spain) that are well known for their cases of environmental pollution. Human milk samples were collected from 50 mothers and inorganic contaminants were analyzed using inductively coupled plasma mass spectrometry (ICP-MS). The mean or maximum concentrations of the different inorganic elements analyzed in breast milk, with the exception of manganese, exceeded the maximum limits established by the WHO and could constitute a high risk for pregnant mothers and their children. The breast milk of women living in the industrial/mining zone presented the highest levels of aluminum, zinc, arsenic, lead, mercury and nickel. On the contrary, the highest concentrations of manganese, chromium and iron were determined in the milk of women living in the agricultural zone. These results suggested and confirmed different profiles of environmental contamination of these areas.

Keywords: human breast milk; inorganic compounds; heavy metals; trace elements; environmental pollution

\section{Introduction}

Breast milk is the most complete and natural food that children can consume during the early stages of their life, as it ensures their proper nutrition and development. An exclusive breastfeeding diet for up to 6 months reduces diseases such as diarrhea or pneumonia and even infant mortality [1].

In addition, breastfeeding contributes to the health and well-being of mothers, helps to space children, reduces the risk of ovarian cancer and breast cancer, increases family and national resources, is a secure way of feeding and is safe for the environment [1]. It even exerts a protective effect when there are high concentrations of toxic substances, as stated by many authors $[2,3]$.

Only in very specific cases have measures of restriction of breast milk been published [4]. Most of the toxic substances passed from mother to child are transferred transplacentally and, to a lesser extent, via breast milk [5-7]. Therefore, the high levels of certain contaminants in milk reflect environmental contamination and not a problem unique to breastfed children. Children are especially vulnerable to different inorganic elements since their detoxification mechanisms are not fully developed and their organs are in formation [4]. Maternal exposure to heavy metals such as $\mathrm{Pb}$ or $\mathrm{Hg}$ is associated 
with children's neurodevelopment delay. The presence of heavy metals in milk-including arsenic, lead, cadmium and mercury-induces changes in the structure of the immune system and also in its function by disturbing the homeostasis. These inorganic elements cause stimulation or suppression of the immunomodulatory components and can indirectly influence various body organs as well as the nervous, reproductive, respiratory and endocrine systems. This can lead to health problems in children such as allergies, disorders in the endocrine system and even neurodevelopment delay and disorder [8].

The trajectory of one's life may be significantly altered depending on where they were born, which may result in exposure to toxicants such as lead, which could subsequently affect biological systems (neurological, hepatic or cardiovascular), ultimately altering income, education level and occupation, for example. The life course approach may be explained by lead exposure during one's lifetime, since exposure to lead increases with age; the pathologies associated with this exposure also increase with age [9].

This exposure starts early as lead crosses the placental barrier, and the fact that it competes with calcium causes it to affect fetal and maternal bone function. Maternal bone is an endogenous source of lead, as a woman who has accumulated lead during her lifetime may have a significant store of lead in her bones. This accumulation suggests that women who have been exposed to lead in the past are at risk of exposing the developing fetus to lead via cord blood and, after birth, through breast milk [9]. Therefore, there is no safe level of exposure to lead or a threshold for adverse effects.

Age at onset, duration and changes in the level of exposure to risk factors such as inorganic elements may alter their effects on adult disease risk and impact on long-term disease trends [10].

We are surrounded by thousands of substances toxic to humans, and milk constitutes a valuable method of analyzing these, serving as a monitoring mechanism for the environmental pollution that surrounds us.

In the southeastern area of the Murcia Region (Spain), over the last century, a large number of industries were derived from mining that obtained lead, silver and zinc, releasing significant amounts of lead and arsenic oxides into the atmosphere, among others [11]. The Bay of Portman is one of the oldest known mining sites, mainly of lead, zinc and others such as pyrite. However, operations were mainly carried out from 1962 onwards out in the open pit, leading to large spills [12]. Studies carried out in the area found a large number of chemical elements with high bioavailability—mainly cadmium, followed by lead and arsenic, among others [13]. In addition, the Escombreras valley industrial complex is also located in that area, which leads to emission of waste with high levels of mercury and caused the waters near the valley to be considered one of the most polluted areas in Europe by the United Nations and by the European Environment Agency.

In order to compare the levels of the different chemical substances found in the milk of mothers in the industrial/mining area, we analyzed a second group of samples from women residing in an agricultural area of Murcia where other chemical substances from fertilizers and pesticides predominate. Due to the characteristics of the study area, inorganic elements (metals and other chemical elements) have special relevance.

Differences in the levels of inorganic contaminants in breast milk may depend on multiple factors, such as maternal factors (anthropometric and sociodemographic characteristics, maternal habits, maternal feeding, etc.), infant factors (age or time of breastfeeding; differentiation depending on whether it is colostrum, transitional milk or mature milk; prematurity, etc.) and others, such as the sampling time (in the morning or at night, at the beginning or at the end of the feeding), the sampling method (collection and transport), environmental factors (level of contamination in the area, exposure or duration), analytical method, contamination of samples, etc. [14-16].

The aim of this study was to quantify the levels of heavy metals and trace elements in samples of breast milk from women living in industrial/mining and agricultural areas, assess the relationship between metal pollutants in breast milk and lifestyle and maternal 
characteristics and evaluate the toxicological risk of exposure to environmental pollutants according to different variables, for both mother and infant.

\section{Materials and Methods}

\subsection{Samples}

Fifty individual breast milk samples were obtained from nursing mothers (primiparous and multiparous women with mixed or exclusive lactation, aged $32.98 \pm 4.04$ years old, who had resided in the represented area for at least the previous 5 years) at a primary care center. The women were residents in the Region of Murcia, south Spain: Cartagena, La Union and Portman were the mining and industry locations, and San Javier was one of the agricultural areas, among others. Thirty percent $(n=15)$ of the mothers lived in an agricultural area during the last five years, while $70 \%(n=35)$ lived in an industrial-mining area. Sixty-two percent $(n=31)$ gave exclusive breastfeeding and 38\% $(n=19)$ alternated breast milk with formula milk. The mean age of babies in the milk collection period was $7.5 \pm 8.5$ months (range: 1-32). The mean number of months of breastfeeding, including the months of breastfeeding in previous children, was 10.51 months.

All the mothers chosen for the study were not occupationally exposed to chemicals. From each of the participants, information was collected about the characteristics of the mother (housewife, place of residence, exclusive breastfeeding, age, weight, body mass index (BMI), size, number of children, years living in an industrial and mining area and total months of breastfeeding in previous children), of the child (age, birth and current weight), maternal habits (consumption of tobacco, glasses of water a day) and maternal nutrition (consumption of fruits, fish, meat and vegetables). The characteristics of the mothers, children and maternal nutrition according to the group (industrial-mining area vs. agricultural area) are shown in Table 1.

The criteria and approach for donor selection and human milk sampling were based on the "Guidelines for Developing a National Protocol" [17]. Milk samples (about $50 \mathrm{~mL}$ ) were hand-expressed or breast-pumped into 100-milliliter pre-cleaned polypropylene pots, and appropriate precautions (washed with a $2 \%$ solution of $\mathrm{HNO} 3$ quality Suprapur and Milli-Q water) were taken to prevent contamination of the samples. All samples were immediately frozen and kept at $-20^{\circ} \mathrm{C}$ until analysis.

Table 1. Characteristics of the mothers, children and maternal nutrition according to the group (industrial-mining area vs. agricultural area).

\begin{tabular}{|c|c|c|c|}
\hline Mother Characteristics & Industrial/Mining Area & Agricultural Area & $p$ \\
\hline Age (years) $($ mean $\pm S D) *$ & $32.57 \pm 4.25$ & $33.93 \pm 3.43$ & 0.297 \\
\hline Weight $(\mathrm{kg})($ mean $\pm \mathrm{SD})$ * & $67.17 \pm 12.43$ & $58.96 \pm 8.59$ & 0.018 \\
\hline Size $(\mathrm{cm})($ mean $\pm \mathrm{SD}) *$ & $163.82 \pm 6.08$ & $162.33 \pm 4.22$ & 0.517 \\
\hline$N$ of children $($ mean $\pm \mathrm{SD}) *$ & $1.91 \pm 0.70$ & $1.40 \pm 0.50$ & 0.013 \\
\hline Housewife $(n, \%) * *$ & $11(31.4)$ & $2(13.3)$ & 0.163 \\
\hline Exclusive breastfeeding $(\mathrm{n}, \%) * *$ & $24(68.6)$ & $7(46.7)$ & 0.341 \\
\hline Years living in the area (mean $\pm \mathrm{SD})$ * & $19.48 \pm 12.83$ & $15.26 \pm 12.48$ & 0.265 \\
\hline $\begin{array}{l}\text { Total months of breastfeeding in previous children } \\
\qquad(\text { mean } \pm \mathrm{SD})\end{array}$ & $13.22 \pm 15.83$ & $7.33 \pm 12.65$ & 0.083 \\
\hline \multicolumn{4}{|l|}{ Child characteristics } \\
\hline Age (months) (mean \pm SD) * & $6.60 \pm 7.65$ & $9.73 \pm 10.20$ & 0.343 \\
\hline Birth weight $(\mathrm{g})($ mean $\pm \mathrm{SD})$ * & $3312.25 \pm 473.70$ & $3105.33 \pm 433.68$ & 0.178 \\
\hline $\begin{array}{l}\text { Current weight }(\mathrm{g})(\text { mean } \pm \mathrm{SD}) \\
\text { Maternal habits }\end{array}$ & \multicolumn{2}{|c|}{ Maternal habits } & 0.452 \\
\hline Smoker or ex-smoker $(n, \%) * *$ & $12(34.3)$ & $5(33.3)$ & 0.608 \\
\hline \multicolumn{4}{|l|}{ Glasses of water a day $(n, \%) * * *$} \\
\hline$<4$ & $4(11.4)$ & 0 & \\
\hline $4-5$ & $13(37.1)$ & $7(46.7)$ & 0.375 \\
\hline$\geq 6$ & $18(51.4)$ & $8(53.3)$ & \\
\hline
\end{tabular}


Table 1. Cont.

\begin{tabular}{|c|c|c|c|}
\hline Mother Characteristics & Industrial/Mining Area & Agricultural Area & $p$ \\
\hline \multicolumn{4}{|l|}{ Maternal nutrition } \\
\hline \multicolumn{4}{|l|}{ Fruit consumption $(\mathrm{n}, \%)$ ** } \\
\hline Weekly & $2(5.7)$ & $1(6.7)$ & 0.666 \\
\hline Daily & $33(94.3)$ & $14(93.3)$ & \\
\hline \multicolumn{4}{|l|}{ Vegetable consumption $(\mathrm{n}, \%) * *$} \\
\hline Weekly & $3(8.6)$ & $2(13.3)$ & 0.476 \\
\hline Daily & $32(91.4)$ & $13(86.7)$ & \\
\hline \multicolumn{4}{|l|}{ Blue fish consumption $(n, \%) * * *$} \\
\hline Never & $12(34.3)$ & $10(66.7)$ & \\
\hline $1-3$ times a month $(n, \%) * * *$ & $14(40)$ & $2(13.3)$ & 0.083 \\
\hline Weekly & $9(25.7)$ & $3(20)$ & \\
\hline \multicolumn{4}{|l|}{ White fish consumption $(n, \%) * * *$} \\
\hline Never & $2(5.7)$ & $2(13.3)$ & \\
\hline 1-3 times a month & $6(17.1)$ & $1(6.7)$ & 0.560 \\
\hline Weekly & $27(77.2)$ & $12(80)$ & \\
\hline \multicolumn{4}{|l|}{ Meat consumption $(n, \%) * * *$} \\
\hline Never & $2(5.7)$ & $3(20)$ & \\
\hline $1-3$ times a month & $6(17.1)$ & $5(33.3)$ & 0.165 \\
\hline Weekly & $22(62.9)$ & $5(33.3)$ & \\
\hline Daily & 5 (14.3) & $2(13.3)$ & \\
\hline
\end{tabular}

SD: standard deviation, ${ }^{*}$ Mann-Whitney $U$ test, ${ }^{* *}$ Pearson chi-square, ${ }^{* * *}$ Fisher test.

\subsection{Materials and Reagents}

The following materials and reagents were used through the study: Suprapur-grade nitric acid and hydrogen peroxide (Merck ${ }^{\circledR}$ ); Milli-Q Plus Millipore double-distilled and deionized water; disposable plastic Pasteur pipettes; adjustable Finnpipette micropipettes (Thermo Electron Corporation, Waltham, MA, US, NA) and disposable plastic tips; screw cap containers; disposable plastic tubes of $15 \mathrm{~mL}$, with snap caps; beakers; 25-milliliter volumetric flasks; Microwave Milestone Ethos Sel. model with Teflon vessels; an ultrasound bath; Agilent 7500 Series ICP-MS equipment with a CETAC ASX-510 autosampler; and commercial stock solutions (Merck ${ }^{\circledR}$ ) for each of the elements.

\subsection{Analysis}

The analytical procedure for the extraction of inorganic elements from human milk samples was similar to that described by Jerez et al. [18]. Briefly, breast milk samples were processed in a Microwave Milestone, Ethos Sel. model, using the "organic up 0.4" digestion program (Table 2). To prevent contamination of the samples, the Teflon vessels used for the digestion of the samples were kept in acid solution ( $2 \%$ solution of HNO3 quality Suprapur and Milli-Q water) for $24 \mathrm{~h}$ and subjected to an ultrasound bath with heat for approximately $2 \mathrm{~h}\left(70^{\circ} \mathrm{C}\right)$. The thawed samples were subjected to a wet digestion using a mixture of $\mathrm{HNO}_{3}(65 \%), \mathrm{H}_{2} \mathrm{O}_{2}(30 \%)$ and double-distilled and deionized water in a ratio 5:2:3, respectively. The resulting digestion was brought to a volume of $25 \mathrm{~mL}$ with double-distilled and deionized water, remaining refrigerated at $4{ }^{\circ} \mathrm{C}$ until analysis by ICP-MS.

The analysis of the inorganic compounds was performed on an Agilent 7500 Series ICP-MS system with a CETAC ASX-510 autosampler, a Peltier-cooled Scott-type nebulizer chamber, a MicroMist concentric nebulizer, nickel cones, $27.12 \mathrm{MHz}$ radio frequency generator and a $1600 \mathrm{~W}$ Fassel-type quartz torch, argon mass flow control in plasma, auxiliary line, adjustment line and carrier gas, a hyperbolic quadrupole mass filter $(3 \mathrm{MHz}$ and 2-260 amu) and a simultaneous digital/analog detector with 9 orders of magnitude of linear dynamic range and a collision/reaction cell. 
Table 2. Characteristics of the Microwave Milestone (Ethos Sel. Model) and "organic up 0.4" program.

\begin{tabular}{cccc}
\hline \multicolumn{4}{c}{ Microwave Milestone: Ethos Sel. Model. } \\
\hline Characteristics & “Organic Up 0.4” Program \\
\hline Closed System & Time (min) & T ( ${ }^{\circ}$ C) & Power (W) \\
\hline 6-sample capacity & 0 & 20 & - \\
High-pressure rotor & 5 & 85 & 700 \\
HPR 1000/6M & 3 & 145 & 500 \\
Automatic temperature sensor & 30 & 210 & 1.000 \\
\hline
\end{tabular}

T-temperature.

The following isotopes were selected for the analysis of the elements: $27 \mathrm{Al}, 52 \mathrm{Cr}$, $55 \mathrm{Mn}, 56 \mathrm{Fe}, 60 \mathrm{Ni}, 63 \mathrm{Cu}, 66 \mathrm{Zn}, 75 \mathrm{As}, 78 \mathrm{Se}, 111 \mathrm{Cd}, 202 \mathrm{Hg}$ and $208 \mathrm{~Pb}$. The sensitivity was $\mathrm{Li}$ (7) $\geq 8 \mathrm{Mcps} / \mathrm{ppm} ; \mathrm{Y}$ (89) $\geq 20 \mathrm{Mcps} / \mathrm{ppm} ; \mathrm{Tl}$ (205) $\geq 12 \mathrm{Mcps} / \mathrm{ppm}$; background (for $5 \mathrm{amu}$ ) $\leq 5$ cps; oxides (in $\mathrm{CeO}+$ ) $\leq 1,0 \%$; divalent cations (in $\mathrm{Ce}^{2+}$ ) $\leq 3.0 \%$ with detection limits of Be (9) $\leq 2 \mathrm{ppt}$, In (115) $\leq 1$ ppt and Bi (209) $\leq 1$ ppt.

The detection limits of the analytical method were as follows: $0.004 \mu \mathrm{g} \mathrm{g}^{-1}(\mathrm{Al})$, $0.0002 \mu \mathrm{g} \mathrm{g}^{-1}$ (Cr, As, Hg), $0.0004 \mu \mathrm{g} \mathrm{g}^{-1}$ (Mn, Ni), $0.002 \mu \mathrm{g} \mathrm{g}^{-1}(\mathrm{Fe}), 0.0008 \mu \mathrm{g} \mathrm{g}{ }^{-1}(\mathrm{Cu}$, $\mathrm{Pb}), 0.003 \mu \mathrm{g} \mathrm{g}^{-1}(\mathrm{Zn}), 0.0007 \mu \mathrm{g} \mathrm{g}^{-1}$ (Se) and $0.0001 \mu \mathrm{g} \mathrm{g}{ }^{-1}$ (Cd). Gallium and rhodium were used as internal standards.

Quality control of the procedure (reproducibility and reliability of the results) was carried out by introducing the samples in duplicate at random, with blanks at the beginning of each series of analyses and every 5 samples. The calibration standards were analyzed initially and periodically. Seven standards of each of the elements were used that were analyzed from commercial stock solutions (Merck ${ }^{\circledR}$ ), which were stabilized with $20 \mu \mathrm{L}$ of HNO3. The concentrations of the standards were 1, 5, 10, 25, 50, 100 and $200 \mathrm{ng} / \mathrm{L}$. In cases where the upper limit of the calibration line was insufficient to detect levels higher than this in the test samples, standards of a higher concentration or dilution of the sample in question were prepared. The correlation index (R2) of the calibration lines was equal to or greater than 0.999 .

\subsection{Statistical Analysis}

The results of the maternal/child characteristics, maternal habits and nutrition and inorganic element concentrations in breast milk were collected in a database (Microsoft Access 11.0; Microsoft corporation, Seattle, WA, USA), and statistical analysis was performed using the SPSS 24.0 software (SPSS Inc., Chicago, IL, USA).

Normality and homogeneity of variance were tested prior to application of the analysis. The Mann-Whitney U-test or the Kruskal-Wallis test was performed to analyze group differences on continuous or ordinal data. Differences between groups on categorical variables were analyzed using Pearson's $\chi^{2}$ or Fisher's exact probability test. Results were expressed as mean \pm standard deviation, median and range or as a percentage. Spearman's rho correlation was used to measure the association between two quantitative variables. $P$-values below 0.05 were considered significant.

\section{Results and Discussion}

The descriptive statistics of the heavy metal and trace element levels found in the breast milk samples are shown in Table 3. Likewise, the percentages that exceed the maximum tolerable limit (MTL) of the different inorganic compounds in breast milk as established by the WHO are detailed with respect to the total of the samples [19], except for aluminum. However, in the case of aluminum, the FAO/WHO established the tolerable daily intake (TDI) as a toxicity control parameter. 
Table 3. Descriptive analysis of the levels of inorganic elements $(\mu \mathrm{g} / \mathrm{L})$ and percentage that exceeds the MTL established by the WHO.

\begin{tabular}{|c|c|c|c|c|c|c|c|c|c|c|}
\hline $\begin{array}{l}\text { Inorganic } \\
\text { Elements }\end{array}$ & Min & Max & Mean & SD & P25 & Median & P75 & $\begin{array}{l}\text { Detection } \\
\text { Percentage }\end{array}$ & $\begin{array}{l}\text { Percentage that Exceeds the } \\
\text { Maximum Tolerable Limit (MTL } \\
\mu \mathrm{g} / \mathrm{L} \text { ) Established by the WHO }\end{array}$ & $\begin{array}{l}\text { Tolerable Daily Intake } \\
\text { (TDI) }(\mu \mathrm{g} / \mathrm{kg} / \mathrm{day})\end{array}$ \\
\hline Al & 0 & 882.4 & 34.3 & 133.0 & 0 & 0 & 0 & $18 \%$ & $18 \%$ * & 1000 \\
\hline As & 0 & 15.3 & 0.9 & 2.71 & 0 & 0 & 0 & $12 \%$ & $12 \%(0.6)$ & 0.3 \\
\hline $\mathrm{Cd}$ & 0 & 7.8 & 0.4 & 1.6 & 0 & 0 & 0 & $6 \%$ & $6 \%(1)$ & 0.4 \\
\hline $\mathbf{P b}$ & 0 & 89.2 & 5.2 & 16.7 & 0 & 0 & 1.9 & $30 \%$ & $12 \%(5)$ & 3.6 \\
\hline $\mathrm{Hg}$ & 0 & 83.6 & 5.6 & 12.4 & 0 & 2.4 & 6.5 & $58 \%$ & $54 \%(1.7)$ & 0.7 \\
\hline Mn & 0 & 450.0 & 10.7 & 63.6 & 0 & 0 & 0 & $16 \%$ & $12 \%(4)$ & 140 \\
\hline $\mathrm{Fe}$ & 0 & 7205.8 & 679.1 & 1387.3 & 0 & 195.7 & 518.5 & $66 \%$ & $18 \%(720)$ & 114 \\
\hline $\mathrm{Ni}$ & 0 & 212.5 & 25.3 & 33.8 & 2.5 & 17.8 & 34.6 & $78 \%$ & $54 \%(16)$ & 12 \\
\hline $\mathrm{Cu}$ & 0.93 & 1217.6 & 368.5 & 301.0 & 160.2 & 262.8 & 486.3 & $100 \%$ & $36 \%(310)$ & 71.4 \\
\hline Se & 0 & 273.0 & 44.5 & 49.5 & 0 & 35.1 & 64.6 & $74 \%$ & $60 \%(24)$ & 30 \\
\hline
\end{tabular}

* Tolerable daily intake (TDI) established by the FAO/WHO; SD: standard deviation, P25: 25th percentile, P75: 75th percentile. 
An infant's daily consumption of breast milk can vary depending on the child's age and its solid food intake. In this study, the calculation of the daily and weekly intake for infants was made considering an average daily rate of milk consumption of $800 \mathrm{~mL} /$ day per infant during the first six months of life and a child's body weight of $6 \mathrm{~kg}$ as reported in the WHO Infant/Child Growth chart (2009) [20]. The daily and weekly intakes were calculated using the following formulas:

$$
\begin{gathered}
\text { Daily intake }\left(\frac{\mu \mathrm{g}}{\mathrm{kg} \text { body weigth }} \text { day }\right)=\frac{\text { milk intake }\left(\frac{\mathrm{L}}{\text { day }}\right) \times \text { contaminant }\left(\frac{\mu \mathrm{g}}{\mathrm{L}}\right)}{\text { body weigth }(\mathrm{kg})} \\
\text { Weekly intake }\left(\frac{\mu \mathrm{\mu g}}{\mathrm{kg} \text { body weigth }} \text { week }\right)=\frac{\text { milk intake }\left(\frac{\mathrm{L}}{\mathrm{day}}\right) \times \text { contaminant }\left(\frac{\mu \mathrm{g}}{\mathrm{L}}\right)}{\text { body weigth }(\mathrm{kg})} \times 7 \text { (days) }
\end{gathered}
$$

Overall, the mean concentrations of the heavy metals and trace elements investigated were higher than those recommended (Table 3).

Lead was detected in 15 samples at higher levels than those reported in studies carried out in Chile [21], Greece [22], Slovakia [23], Sweden [24], Spain [25], Portugal [26], Italy [27] and Mexico [28]. The mother with the highest level of lead in her milk corresponds to a 28-year-old multiparous woman who has resided in the industrial/mining area for more than 5 years, with a university degree, who smokes or has smoked in the past and with a nursing child of 3 months. The weekly intake would be $83.62 \mu \mathrm{g} / \mathrm{kg} /$ week, a value higher than the reference of $25 \mu \mathrm{g} / \mathrm{kg} /$ week established by the EFSA [29].

Cadmium was detected in 3 of the 50 samples with a mean concentration similar to those found in breast milk samples from women in Poland [30], lower than those in Lebanon [31] and higher than those in Sweden [24], Greece [22], Italy [27] and Brazil [32]. The three samples exceeded the maximum recommended limits. The mothers with cadmium in their milk were women aged between 32 and 36 years, with normal weight (BMI around 22), two of them resident in an agricultural area and the other in an industrial/mining area, working outside of the home, with a smoking habit and with one-monthold children.

Mercury was detected at a mean concentration higher than that referenced in different studies carried out in Austria [33,34], China [35], Germany [36,37], Sweden [38], Slovakia [23,39], Turkey [40], Cyprus [41] and Brazil [32]. Twenty-seven samples exceeded the maximum tolerable limit. The mother with the highest level of mercury in her milk was a 38-year-old woman with normal weight, with two children, a housewife who had worked in greenhouses in the past, residing in the industrial/mining area, consuming fish weekly and with a 6-month-old infant.

Copper was detected at a mean concentration higher than the concentrations in other work published in Poland [30,42], Sweden [24], Portugal [26], Italy [27] and Saudi Arabia [43] but lower than those found in Nigeria [44], Greece [22] and Turkey [45]. Eighteen samples exceeded the maximum tolerable level of copper. The mothers with the highest levels of copper in their milk were women over 35 years of age with normal weight, multiparous, mostly residents in the agricultural area, with daily fruit consumption and weekly potato intake and vitamin intake only in pregnancy.

Zinc was detected in 36 samples, of which 11 exceeded the permitted intake limit. The mean zinc levels were higher than those found in other studies in Santiago, Chile [21]; Arica, Chile [21]; Sweden [24]; Portugal [26] and Italy [27]. The mothers with the highest levels of zinc in milk were women aged between 26 and 35 years old and of normal weight, all residents in the industrial/mining area, with prolonged breastfeeding (more than 20 months), except a mother with only one month of breastfeeding with vitamin consumption only in pregnancy.

Arsenic was detected in six samples. The mean values found are higher than most of those found in the reviewed literature [32,41,46,47]. All samples with arsenic exceeded the maximum tolerance limit. The mother with the highest level of arsenic in milk was a 36-year-old woman with normal weight, primiparous, who works outside the home, 
resides in the industrial/mining zone, with weekly fish consumption, a smoker and with a nursing son of 1 month.

Iron was detected in 33 samples with a mean concentration higher than in most publications [22,24,32,48-50]. Nine samples exceeded the maximum allowed level (350$720 \mu \mathrm{g} / \mathrm{L})$. The mother with the highest level of iron in milk was a 37-year-old woman with normal weight, with two children, a housewife, a resident of the agricultural area, without intake of iron supplements and with a 24-month-old nursing son.

Thirty-nine mothers had detectable levels of nickel in their milk. Compared with the levels found in other studies, these results are higher than those of most authors [24,32,51,52]. The mother with the highest level of nickel in milk was a 36-year-old multiparous woman residing in the industrial/mining zone, who works outside the home, taking vitamin supplements during pregnancy and breastfeeding, with a baby of 3 months and a total of 3 months of breastfeeding, including the time for previous children.

Chromium was detected in 49 samples at a mean concentration higher than those found in other works [24,32,46,53-57]. Forty-six samples presented levels above the allowed limit. The mother with the highest level of chromium in milk was a 37-year-old multiparous woman, living in the agricultural area, working outside the home, consuming vitamin complexes during pregnancy and a smoker with a 24-month-old infant.

Selenium was detected in 37 samples at a mean concentration higher than those in other studies [24,26,32,58-63]. Thirty samples showed levels above the allowed limit. The mother with the highest level of selenium in milk was a 36-year-old multiparous woman residing in the industrial/mining area, working outside the home, consuming dairy products daily and meat several times a week, with intake of vitamin supplements during pregnancy and lactation and with a child of 3 months and a total of months of breastfeeding including the time for previous children of 3 months. This same mother had had the highest levels of aluminum and nickel in her milk.

Manganese was detected in eight samples at a mean concentration higher than that in different published studies $[24,32,47,53,64,65]$. Six samples exceeded the maximum limit allowed. The mother with the highest level of manganese in milk was a 38-year-old woman with normal weight, with two children, a housewife who in the past had worked in greenhouses, residing in the industrial/mining zone, with consumption of meat and fish weekly and of dairy daily, with exclusive breastfeeding and with a 6-month-old suckling child. This mother also had the highest level of mercury in her milk.

\subsection{Relationship between Levels of Inorganic Pollutants and Characteristics of Mothers}

The relationships between the heavy metals and trace elements studied and the most significant characteristics of mothers are shown in Table 4.

The highest levels of aluminum, nickel, selenium, arsenic, lead, zinc and mercury in breast milk were found in women residing in the industrial and mining zone, which may be due to the fact that the study area is strongly affected by these anthropogenic activities, which make it the zone containing the most severely metal-contaminated sediments in the Mediterranean area [66,67]. However, the highest levels of chromium, iron, copper and manganese were found in women who resided in the agricultural zone, although these differences were not statistically significant. Regarding age, a positive and significant correlation (Spearman's correlation coefficient $(r s=0.425 ; p=0.002$ ) was observed with the level of aluminum in breast milk, similar to that reported by Mandić et al. [68], probably by bioaccumulation. No statistically significant correlations were observed between the items and housewife status, weight, height, BMI, number of children and total months of breastfeeding in previous children. 
Table 4. Levels of inorganic elements in breast milk $(\mu \mathrm{g} / \mathrm{L})$ according to characteristics, diet and habits of mothers.

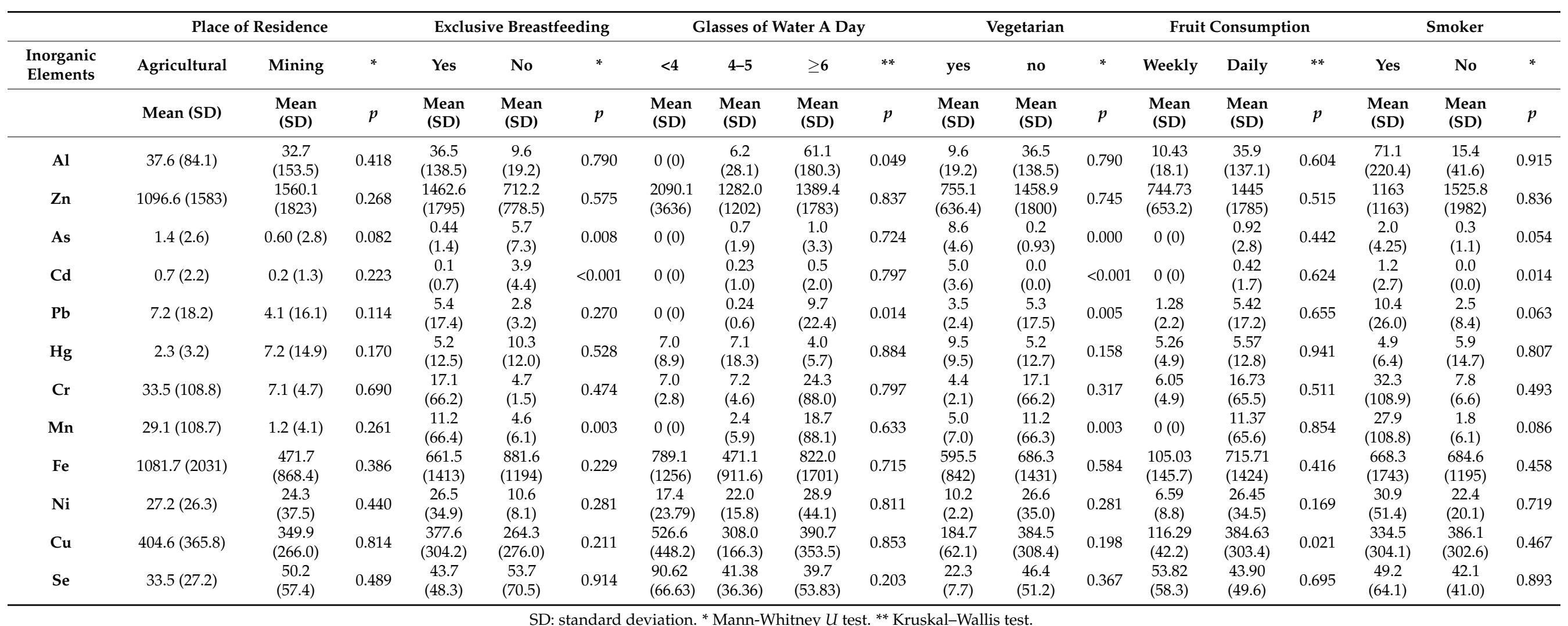


Residence time in the industrial/mining area positively correlated with the concentration of nickel in breast milk ( $r s=0.493 ; p<0.001)$. Exclusive breastfeeding positively correlated with manganese levels-i.e., its concentration increases if breastfeeding is exclusive $(p=0.003)$. The concentrations of arsenic and cadmium were significantly lower in the milk of mothers who exclusively breastfed compared to mothers who fed their children with mixed lactation ( $p=0.008$ and $p<0.001$, respectively). In exclusive breastfeeding, the feeding of the child is not complemented with other formula milks, with the milk production being greater, and therefore, there is maternal elimination of heavy metals [69]. García-Esquinas et al. [70] found the same result for cadmium.

\subsection{Maternal Diet and Habits}

The relationships between the heavy metals and trace elements studied and the most significant diet and habits of mothers are shown in Table 4. Mothers with a higher daily water intake had higher levels of lead and aluminum in their milk than those who consumed less water. Industrial spills and old plumbed pipes can cause lead to be elevated in drinking water, which could explain this fact. An Egyptian study found the same results [71]. On the other hand, the intake of aluminum through drinking water is generally low. However, we found that the aluminum levels in the breast milk of women who consumed the most water per day were significantly higher than those in mothers who consumed the least amount of water daily; as water is sometimes treated with aluminum salts during the drinking water production process, this could explain the increase in this metal in relation to the amount consumed.

Women who consumed fruit daily had higher levels of copper in their milk than women who consumed it weekly $(p=0.021)$. Copper is present in pesticides, and residues can be found in fruits, which may explain the values found [22].

The level of cadmium and arsenic in breast milk was significantly higher in vegetarian women compared to those who were not. For both arsenic and cadmium, plants are one of their sources of exposure, which would explain this result. Leotsinidis et al. [22] found higher levels of cadmium in the milk of mothers with high vegetable consumption. The Mann-Whitney U-test showed that lead and manganese levels are significantly higher in non-vegetarian women.

Despite the fact that fish intake is considered the main source of mercury of non-labor origin, we did not find significant differences in the levels of mercury in the milk of women with high consumption of fish in general, shellfish or tuna $(p=0.539)$. These results coincide with those published by García-Esquinas et al. [70] and Gundacker et al. [34], probably due to the homogeneity in the consumption of the sample or due to the low passage into breast milk of the organic mercury present in the fish [6]. The concentrations in breast milk of the inorganic elements were not significantly different according to the consumption of meat or fish. However, despite the differences not being statistically significant, an increase in lead and mercury concentrations was observed with higher frequency of fish intake (levels of lead, mean $\pm \mathrm{SD}(\mu \mathrm{g} / \mathrm{L})$, according to fish consumption: never, $2.61 \pm 8.41 ; 1-3$ times a month, $6.74 \pm 17.74$; weekly, $7.75 \pm 25.67, p=0.570$; levels of mercury, mean $\pm \mathrm{SD}(\mu \mathrm{g} / \mathrm{L})$, according fish consumption: never, $3.91 \pm 5.87$; $1-3$ times a month, $3.75 \pm 4.67$; weekly, $10.97 \pm 23.42, p=0.539$ ).

It was observed that mothers with current or past smoking habits had higher levels of cadmium in their milk than those who did not, coinciding with the results of many other authors $[23,30,70,72-75]$. Tobacco contains high concentrations of cadmium (0.1 to $0.2 \mu \mathrm{g}$ per cigarette) that is easily absorbed through the respiratory tract [76]. Other works did not find such differences [22,75]. Arsenic was also positively correlated with cigarette smoking by mothers. Tobacco contains derivatives of arsenic as an irritant [77]; for this reason, it is reasonable to think that this habit in the mother would increase the levels of the toxin in breast milk. Chao et al. [75] found no such differences. 
With regard to smoking, significant differences were observed in cadmium concentration ( $p=0.014$ ) between women who smoked or who had smoked at some point in their lives and non-smokers, with the cadmium concentration being higher in smokers.

\subsection{Children's Characteristics}

Regarding the sex of the baby, no significant differences were observed in the concentrations of inorganic elements between boys and girls. A negative and significant correlation was observed between the concentrations of zinc and cadmium ( $r s=-0.392, p=0.005$ and $r s=-0.353, p=0.012$, respectively) and the baby's age and birth weight (Table 5).

Table 5. Correlations of levels of inorganic elements in breast milk vs. child's age, birth weight and current weight.

\begin{tabular}{|c|c|c|c|c|}
\hline \multirow{3}{*}{$\begin{array}{c}\text { Inorganic Elements } \\
\text { Al }\end{array}$} & \multicolumn{2}{|c|}{ Age } & \multirow{2}{*}{$\begin{array}{c}\text { Birth Weight } \\
-0.214\end{array}$} & \multirow{2}{*}{$\begin{array}{c}\text { Current Weight } \\
-0.062\end{array}$} \\
\hline & $r_{S}$ & 0.051 & & \\
\hline & $p$ & 0.726 & 0.136 & 0.669 \\
\hline \multirow{2}{*}{ Zn } & $r_{S}$ & $-0.392^{* *}$ & 0.151 & -0.227 \\
\hline & $p$ & 0.005 & 0.294 & 0.112 \\
\hline \multirow{2}{*}{ As } & $r_{S}$ & -0.269 & $-0.392 * *$ & -0.250 \\
\hline & $p$ & 0.059 & 0.005 & 0.080 \\
\hline \multirow{2}{*}{$\mathrm{Cd}$} & $r_{S}$ & $-0.353 *$ & -0.249 & $-0.294 *$ \\
\hline & $p$ & 0.012 & 0.081 & 0.038 \\
\hline \multirow{2}{*}{$\mathrm{Pb}$} & $r_{S}$ & -0.072 & -0.125 & -0.160 \\
\hline & $p$ & 0.618 & 0.387 & 0.267 \\
\hline \multirow{2}{*}{$\mathrm{Hg}$} & $r_{S}$ & -0.077 & 0.045 & 0.019 \\
\hline & $p$ & 0.596 & 0.759 & 0.897 \\
\hline \multirow{2}{*}{$\mathrm{Cr}$} & $r_{S}$ & 0.067 & 0.044 & -0.083 \\
\hline & $p$ & 0.644 & 0.760 & 0.564 \\
\hline \multirow{2}{*}{ Mn } & $r_{S}$ & -0.182 & -0.118 & -0.269 \\
\hline & $p$ & 0.206 & 0.415 & 0.059 \\
\hline \multirow{2}{*}{$\mathrm{Fe}$} & $r_{S}$ & -0.045 & -0.007 & -0.056 \\
\hline & $p$ & 0.754 & 0.959 & 0.697 \\
\hline \multirow{2}{*}{$\mathbf{N i}$} & $r_{S}$ & 0.166 & 0.010 & -0.014 \\
\hline & $p$ & 0.249 & 0.948 & 0.924 \\
\hline \multirow{2}{*}{$\mathrm{Cu}$} & $r_{S}$ & -0.205 & 0.140 & $-0.335^{*}$ \\
\hline & $p$ & 0.152 & 0.331 & 0.017 \\
\hline \multirow{2}{*}{ Se } & $r_{\mathrm{s}}$ & -0.017 & -0.017 & -0.004 \\
\hline & $p$ & 0.909 & 0.909 & 0.977 \\
\hline
\end{tabular}

$\mathrm{r}_{\mathrm{s}}$ : Spearman's correlation coefficient. ${ }^{*} p<0.05 ;{ }^{* *} p<0.01$.

Cadmium was negatively correlated with the age and current weight of the child ( $r s=-0.294 ; p=0.038)$, coinciding with the results of other authors $[22,75,78]$. The older the child is, the greater the milk production is and the greater the transfer of cadmium and zinc from the mother to the child is, thus depleting the maternal deposits. On the other hand, the milk of the first months contains higher amounts of proteins, to which cadmium and zinc are strongly bound; as lactation progresses and the milk is more mature, these decrease along with the inorganic elements [26,75]. These results coincide with those of other studies showing that the zinc concentration is higher in the first six months of breastfeeding [30]. Örün et al. [74] found this same negative correlation between cadmium levels and weight, although only in girls, while Ursinyova and Masanova [23] did not find such a relationship. Copper was negatively and significantly correlated with the current weight of the baby $(r s=-0.335 ; p=0.017)$. Arsenic concentration showed a significant negative correlation with birth weight in our study ( $\mathrm{rs}=-0.392 ; p=0.005)$. Arsenic, like cadmium, crosses the transplacental barrier, causing lower weight in the newborn [79].

The main limitation of the study is the limited sample size. However, most studies have a similar sample size [8], probably due to the difficulty of collecting these samples, their nature and ethical implications. As this is the first study of these characteristics carried 
out in an area of special contamination by inorganic elements, we believe that the data reported may be of interest to the scientific community.

\section{Conclusions}

This study quantifies the levels of heavy metals and trace elements in samples of breast milk from women in industrial/mining and agricultural areas. The relationship between metal pollutants in breast milk and lifestyle and maternal characteristics was assessed, and the toxicological risk of exposure to environmental pollutants according to different variables was evaluated, for both mothers and infants. The mean-maximum concentrations of the different inorganic elements analyzed in breast milk exceeded the concentrations recommended by the WHO and other international organizations, which could constitute a high risk for pregnant mothers and their children. The breast milk of women living in the industrial/mining zone for more than 5 years presented the maximum levels of aluminum, zinc, arsenic, lead, mercury and nickel, and the number of years living there was positively correlated with the levels of nickel. On the contrary, the highest concentrations of manganese, chromium and iron were determined in the milk of women living in the agricultural zone. These results suggested and confirmed different profiles of environmental contamination of these areas.

The levels of cadmium and zinc in breast milk were lower in mothers with older children, which would confirm the theory of the passage of toxic substances from the mother to the child during lactation, thus reducing their presence in the mother. Cadmium and copper levels were higher in the milk of mothers of children with lower current weight; in turn, arsenic levels were higher in the milk of women with children of a lower birth weight, which would confirm that exposure to high concentrations of certain toxic substances is associated with low infant weight.

Diet significantly influences the levels of certain elements in breast milk-for example, the amount of water consumed by the mother was associated with higher concentrations of aluminum and lead; vegetarian diets were associated with higher levels of lead, arsenic, cadmium and manganese; and high consumption of fruit was associated with an increase in copper concentrations. Promoting and defending breastfeeding is the responsibility of society as a whole, and being able to maximize its benefits means minimizing the mother's and newborn's exposure to different pollutants. Thus, actions must be taken to reduce and control pollutants by the competent authorities, as well as limiting certain habits and foods that are not recommended due to their high content of toxic substances.

Author Contributions: Conceptualization, M.M. and M.D.P.-C.; methodology, M.M.; software, M.D.P.-C.; validation, M.M., J.O., M.Á.C. and M.D.P.-C.; formal analysis, S.J.; investigation, S.J.; resources, S.J., M.M. and M.D.P.-C.; data curation, S.J. and M.D.P.-C.; writing-original draft preparation, M.M., S.J. and M.Á.C.; writing—review and editing, M.M. and M.D.P.-C.; visualization, J.O. and M.Á.C.; supervision, M.M.; project administration, M.D.P.-C.; funding acquisition, M.M. and M.D.P.-C. All authors have read and agreed to the published version of the manuscript.

Funding: This research received no external funding.

Institutional Review Board Statement: The study was conducted according to the guidelines of the Declaration of Helsinki and approved by the Ethics Committee of the University of Murcia (protocol code CEI 901/2014, date of approval 12 July 2014).

Informed Consent Statement: Informed consent was obtained from all subjects involved in the study. Written informed consent was obtained from the patient(s) to publish this paper.

Data Availability Statement: The data presented in this study are available on request from the corresponding author.

Acknowledgments: We would like to thank the breastfeeding group Cartagena and Mar Menor "Lactancia madre a madre" for the collection and provision of human milk samples, and also the laboratory of instrumental analysis of SAI of University of Murcia, Spain, for laboratory support.

Conflicts of Interest: The authors declare no conflict of interest. 


\section{References}

1. WHO. Guideline: Counselling of Women to Improve Breastfeeding Practices. 2018. Available online: https://www.who.int/ publications/i/item/9789241550468 (accessed on 29 March 2021).

2. Ribas-Fitó, N.; Cardo, E.; Sala, M.; Eulàlia de Muga, M.; Mazón, C.; Verdú, A.; Kogevinas, M.; Grimalt, J.O.; Sunyer, J. Breastfeeding, exposure to organochlorine compounds, and neurodevelopment in infants. Pediatrics 2003, 111 Pt 1, 580-585. [CrossRef]

3. Vreugdenhil, H.J.; Van Zanten, G.A.; Brocaar, M.P.; Mulder, P.G.; Weisglas-Kuperus, N. Prenatal exposure to polychlorinated biphenyls and breastfeeding: Opposing effects on auditory P300 latencies in 9-year-old Dutch children. Dev. Med. Child. Neurol. 2004, 46, 398-405. [CrossRef] [PubMed]

4. Mead, M.N. Contaminants in human milk: Weighing the risks against the benefits of breastfeeding. Environ. Health Perspect. 2008, 116, 427-434. [CrossRef]

5. Needham, L.L.; Wang, R.Y. Analytic considerations for measuring environmental chemicals in breast milk. Environ. Health Perspect. 2002, 110, 317-324. [CrossRef]

6. Solomon, G.M.; Weiss, P.M. Chemical Contaminants in Breast Milk: Time Trends and Regional Variability. Environ. Health Perspect. 2002, 110, 339-347. [CrossRef] [PubMed]

7. Cerna, M.; Spevackova, V.; Batariova, A.; Smid, J.; Cejchanova, M.; Ocadlikova, D.; Bavorová, H.; Beneš, B.; Kubínová, R. Human biomonitoring system in the Czech Republic. Int. Environ. Health 2007, 210, 495-499. [CrossRef] [PubMed]

8. Pajewska-Szmyt, M.; Sinkiewicz-Darol, E.; Gadzała-Kopciuch, R. The impact of environmental pollution on the quality of mother's milk. Environ. Sci. Pollut. Res. Int. 2019, 26, 7405-7427. [CrossRef] [PubMed]

9. Obeng-Gyasi, E. Lead exposure and oxidative stress-A life course approach in US adults. Toxics 2018, 6, 42. [CrossRef] [PubMed]

10. Kuh, D.; Ben-Shlomo, Y.; Lynch, J.; Hallqvist, J.; Power, C. Life course epidemiology. J. Epidemiol. Community Health 2003, 57, 778-783. [CrossRef]

11. Benedetti, M.; Iavarone, I.; Comba, P.; Lavarone, I. Cancer risk associated with residential proximity to industrial sites: A review. Arch. Environ. Health 2001, 56, 342-349. [CrossRef]

12. Ramade, F. Assessment of damage to ecosystems: A major issue in ecotoxicological research. Qual. Assur. 1997, 5, 199-220.

13. Navarro, M.C.; Pérez-Sirvent, C.; Martínez-Sánchez, M.J.; Vidal, J.; Marimón, J. Lead, cadmium and arsenic bioavailability in the abandoned mine site of Cabezo Rajao (Murcia, SE Spain). Chemosphere 2006, 63, 484-489. [CrossRef] [PubMed]

14. Iyengar, V.; Woittiez, J. Trace elements in human clinical specimens: Evaluation of literature data to identify reference values. Clin. Chem. 1988, 34, 474-481. [CrossRef]

15. Casey, C.; Smith, A.; Zhang, P.; Jensen, R. Microminerals in human and animal milks. In Handbook of Milk Composition; Academic Press: Cambridge, MA, USA, 1995; pp. 622-674.

16. Ettinger, A.S.; Téllez-Rojo, M.M.; Amarasiriwardena, C.; González-Cossío, T.; Peterson, K.E.; Aro, A.; Hu, H.; Hernández-Avila, M. Levels of lead in breast milk and their relation to maternal blood and bone lead levels at one month postpartum. Environ. Health Perspect. 2004, 112, 926-931. [CrossRef] [PubMed]

17. WHO. Fourth WHO-Coordinated Survey of Human Milk for Persistent Organic Pollutants in Cooperation with UNEP; Guidelines for Developing a National Protocol; World Health Organization: Geneva, Switzerland, 2007.

18. Jerez, S.; Motas, M.; Cánovas, R.A.; Talavera, J.; Almela, R.M.; Del Río, A.B. Accumulation and tissue distribution of heavy metals and essential elements in loggerhead turtles (Caretta caretta) from Spanish Mediterranean coastline of Murcia. Chemosphere 2010, 78, 256-264. [CrossRef] [PubMed]

19. WHO. Minor and Trace Elements in Breast Milk: Report of a Joint W.H.O.; World Health Organization: Geneva, Switzerland, 1989.

20. WHO Infant. Standards: WHO Child Growth Standards/Weight-for-Age; WHO. 2009. Available online: https://www.who.int/ tools / child-growth-standards/standards / weight-for-age (accessed on 29 March 2021).

21. Castro, F.; Harari, F.; Llanos, M.; Vahter, M.; Ronco, A.M. Maternal-child transfer of essential and toxic elements through breast milk in a mine-waste polluted area. Am. J. Perinatol. 2014, 31, 993-1002. [CrossRef]

22. Leotsinidis, M.; Alexopoulos, A.; Kostopoulou-Farri, E. Toxic and essential trace elements in human milk from Greek lactating women: Association with dietary habits and other factors. Chemosphere 2005, 61, 238-247. [CrossRef] [PubMed]

23. Ursinyova, M.; Masanova, V. Cadmium, lead and mercury in human milk from Slovakia. Food Addit. Contam. 2005, 22, 579-589. [CrossRef] [PubMed]

24. Björklund, K.L.; Vahter, M.; Palm, B.; Grandér, M.; Lignell, S.; Berglund, M. Metals and trace element concentrations in breast milk of first time healthy mothers: A biological monitoring study. Environ. Health Glob. Access Sci. Source 2012, 11, 92. [CrossRef]

25. Rodríguez, E.; Delgado, E.; Díaz, C. Concentrations of cadmium and lead in different types of milk. Unters 1999, 208, 162-168. [CrossRef]

26. Almeida, A.A.; Lopes, C.M.P.V.; Silva, A.M.S.; Barrado, E. Trace elements in human milk: Correlation with blood levels, interelement correlations and changes in concentration during the first month of lactation. J. Trace Elem. Med. Biol. Organ. Soc. Miner. Trace Elem. (GMS) 2008, 22, 196-205. [CrossRef]

27. Abballe, A.; Ballard, T.J.; Dellatte, E.; di Domenico, A.; Ferri, F.; Fulgenzi, A.R.; Grisanti, G.; Iacovella, N.; Ingelido, A.M.; Malisch, R.; et al. Persistent environmental contaminants in human milk: Concentrations and time trends in Italy. Chemosphere 2008, 73 (Suppl. 1), 220-227. [CrossRef] 
28. Ettinger, A.S.; Roy, A.; Amarasiriwardena, C.J.; Smith, D.; Lupoli, N.; Mercado-García, A.; Lamadrid-Figueroa, H.; Tellez-Rojo, M.M.; Hu, H.; Hernández-Avila, M. Maternal blood, plasma, and breast milk lead: Lactational transfer and contribution to infant exposure. Environ. Health Perspect. 2014, 122, 87-92. [CrossRef]

29. EFSA. Panel on Contaminants in the Food Chain (CONTAM); Scientific Opinion on Lead in Food. EFSA J. 2010, 8, 151. [CrossRef]

30. Winiarska-Mieczan, A. Cadmium, lead, copper and zinc in breast milk in Poland. Biol. Trace Elem. Res. 2014, 157, 36-44. [CrossRef]

31. Bassil, M.; Daou, F.; Hassan, H.; Yamani, O.; Kharma, J.A.; Attieh, Z.; Elaridi, J. Lead, cadmium and arsenic in human milk and their socio-demographic and lifestyle determinants in Lebanon. Chemosphere 2018, 191, 911-921. [CrossRef] [PubMed]

32. Oliveira, M.M.; Trevilato, T.M.B.; Segura-Muñoz, S.I.; Aragon, D.C.; Alves, L.G.; Nadal, M.; Marquès, M.; Domingo, J.L.; Sierra, J.; Camelo, J.S., Jr. Essential and toxic elements in human milk concentrate with human milk lyophilizate: A preclinical study. Environ. Res. 2020, 188, 109733. [CrossRef] [PubMed]

33. Gundacker, C.; Pietschnig, B.; Wittmann, K.J.; Lischka, A. Human milk mercury (Hg) and lead (Pb) levels in Vienna. Adv. Exp. Med. Biol. 2000, 478, 387-388.

34. Gundacker, C.; Pietschnig, B.; Wittmann, K.J.; Lischka, A.S.; Alzer, H.; Hohenauer, L.; Schuster, E. Lead and mercury in breast milk. Pediatrics 2002, 110, 873-878. [CrossRef]

35. Vimy, M.J.; Hooper, D.E.; King, W.W.; Lorscheider, F.L. Mercury from maternal «silver» tooth fillings in sheep and human breast milk. A source of neonatal exposure. Biol. Trace Elem. Res. 1997, 56, 143-152. [CrossRef]

36. Schramel, P.; Hasse, S.; Ovcar-Pavlu, J. Selenium, cadmium, lead, and mercury concentrations in human breast milk, in placenta, maternal blood, and the blood of the newborn. Biol. Trace Elem. Res. 1988, 15, 111-124. [CrossRef]

37. Drexler, H.; Schaller, K.H. The mercury concentration in breast milk resulting from amalgam fillings and dietary habits. Environ. Res. 1998, 77, 124-129. [CrossRef]

38. Oskarsson, A.; Schültz, A.; Skerfving, S.; Hallén, I.P.; Ohlin, B.; Lagerkvist, B.J. Total and inorganic mercury in breast milk in relation to fish consumption and amalgam in lactating women. Arch. Environ. Health 1996, 51, 234-241. [CrossRef]

39. Uhnák, J.; Ursinyova, M.; Veningerova, M.; Prachar, V.; Rosival, L.; Hladikova, V. Evaluation of Impact of Chemical Substances on Health of Children, Final Report of the Research Project; Institute of Preventive and Clinical Medicine Bratislava: Bratislava, Slovakia, 1994.

40. Yalçin, S.S.; Yurdakök, K.; Yalçin, S.; Engür-Karasimav, D.; Coşkun, T. Maternal and environmental determinants of breast-milk mercury concentrations. Turk. J. Pediatr. 2010, 52, 1-9.

41. Kunter, İ.; Hürer, N.; Gülcan, H.O.; Öztürk, B.; Doğan, İ.; Şahin, G. Assessment of Aflatoxin M1 and Heavy Metal Levels in Mothers Breast Milk in Famagusta, Cyprus. Biol. Trace Elem. Res. 2017, 175, 42-49. [CrossRef] [PubMed]

42. Wasowicz, W.; Gromadzinska, J.; Szram, K.; Rydzynski, K.; Cieslak, J.; Pietrzak, Z. Selenium, zinc, and copper concentrations in the blood and milk of lactating women. Biol. Trace Elem. Res. 2001, 79, 221-233. [CrossRef]

43. Al-Saleh, I.; Shinwari, N.; Mashhour, A. Heavy metal concentrations in the breast milk of Saudi women. Biol. Trace Elem. Res. 2003, 96, 21-37. [CrossRef]

44. Adesiyan, A.A.; Akiibinu, M.O.; Olisekodiaka, M.J.; Onuegbu, A.J.; Adeyeye, A.D. Concentrations of some biochemical parameters in breast milk of a population of Nigerian nursing mothers using hormonal contraceptives. Pak. J. Nutr. 2011, 10, 249-253. [CrossRef]

45. Kılıç Altun, S.; Dinç, H.; Temamoğulları, F.K.; Paksoy, N. Analyses of Essential Elements and Heavy Metals by Using ICP-MS in Maternal Breast Milk from Şanlıurfa, Turkey. Int. J. Anal. Chem. 2018, 2018, 1784073. [CrossRef] [PubMed]

46. Samiee, F.; Vahidinia, A.; Taravati Javad, M.; Leili, M. Exposure to heavy metals released to the environment through breastfeeding: A probabilistic risk estimation. Sci. Total Environ. 2019, 650 (Pt. 2), 3075-3083. [CrossRef]

47. Parr, R.M.; DeMaeyer, E.M.; Iyengar, V.G.; Byrne, A.R.; Kirkbright, G.F.; Schöch, G.; Niinistö, L.; Pineda, O.; Vis, H.L.; Hofvander, Y.; et al. Minor and trace elements in human milk from Guatemala, Hungary, Nigeria, Philippines, Sweden, and Zaire. Results from a WHO/IAEA joint project. Biol. Trace Elem. Res. 1991, 29, 51-75. [CrossRef]

48. Silvestre, M.D.; Lagarda, M.J.; Farré, R.; Martínez-Costa, C.; Brines, J.; Molina, A.; Clemente, G. A study of factors that may influence the determination of copper, iron, and zinc in human milk during sampling and in sample individuals. Biol. Trace Elem. Res. 2000, 76, 217-227. [CrossRef]

49. Maru, M.; Birhanu, T.; Tessema, D.A. Calcium, magnesium, iron, zinc and copper, compositions of human milk from populations with cereal and «enset» based diets. Ethiop. J. Health Sci. 2013, 23, 90-97. [PubMed]

50. Nakamori, M.; Ninh, N.X.; Isomura, H.; Yoshiike, N.; Hien, V.T.T.; Nhug, B.T.; Van Nhien, N.; Nakano, T.; Khan, N.C.; Yamamoto, S. Nutritional status of lactating mothers and their breast milk concentration of iron, zinc and copper in rural Vietnam. J. Nutr. Sci. Vitaminol. 2009, 55, 338-345. [CrossRef] [PubMed]

51. Casey, C.E.; Neville, M.C. Studies in human lactation 3: Molybdenum and nickel in human milk during the first month of lactation. Am. J. Clin. Nutr. 1987, 45, 921-926. [CrossRef]

52. Cinar, N.; Ozdemir, S.; Yucel, O.; Ucar, F. In which regions is breast-feeding safer from the impact of toxic elements from the environment? Bosn. J. Basic Med. Sci. 2011, 11, 234-239. [CrossRef]

53. Casey, C.E.; Neville, M.C.; Hambidge, K.M. Studies in human lactation: Secretion of zinc, copper, and manganese in human milk. Am. J. Clin. Nutr. 1989, 49, 773-785. [CrossRef] [PubMed]

54. Cocho, J.A.; Cervilla, J.R.; Rey-Goldar, M.L.; Fdez-Lorenzo, J.R.; Fraga, J.M. Chromium content in human milk, cow's milk, and infant formulas. Biol. Trace Elem. Res. 1992, 32, 105-107. [CrossRef] 
55. Anderson, R.A.; Bryden, N.A.; Patterson, K.Y.; Veillon, C.; Andon, M.B.; Moser-Veillon, P.B. Breast milk chromium and its association with chromium intake, chromium excretion, and serum chromium. Am. J. Clin. Nutr. 1993, 57, 519-523. [CrossRef] [PubMed]

56. Yoshida, M.; Takada, A.; Hirose, J.; Endô, M.; Fukuwatari, T.; Shibata, K. Molybdenum and chromium concentrations in breast milk from Japanese women. Biosci. Biotechnol. Biochem. 2008, 72, 2247-2250. [CrossRef]

57. Sun, Z.; Yue, B.; Yang, Z.; Li, X.; Wu, Y.; Yin, S. Determination of 24 minerals in human milk by inductively coupled plasma mass spectrometry with microwave digestion. Wei Sheng Yan Jiu J. Hyg. Res. 2013, 42, 504-509.

58. Robberecht, H.; Benemariya, H.; Deelstra, H. Daily dietary intake of copper, zinc, and selenium of exclusively breast-fed infants of middle-class women in Burundi, Africa. Biol. Trace Elem. Res. 1995, 49, 151-159. [CrossRef] [PubMed]

59. Krachler, M.; Li, F.S.; Rossipal, E.; Irgolic, K.J. Changes in the concentrations of trace elements in human milk during lactation. J. Trace Elem. Med. Biol. Organ. Soc. Miner. Trace Elem. (GMS) 1998, 12, 159-176. [CrossRef]

60. Torres, M.A.; Verdoy, J.; Alegria, A.; Barbera, R.; Farre, R.; Lagarda, M.J. Selenium contents of human milk and infant formulas in Spain. Sci. Total Environ. 1999, 228, 185-192. [CrossRef]

61. Yanadarg, R.; Orak, H. Selenium content of milk and milk products of Turkey. II. Biol. Trace Elem. Res. 1999, 68, 79-95.

62. Dylewski, M.L.; Neville, M.C.; Picciano, M.F. Longitudinal profile of human milk selenium from birth to 1 year. FASEB 2001, 15, 599.

63. Hannan, M.A.; Dogadkin, N.N.; Ashur, I.A.; Markus, W.M. Copper, selenium, and zinc concentrations in human milk during the first three weeks of lactation. Biol. Trace Elem. Res. 2005, 107, 11-20. [CrossRef]

64. Dörner, K.; Dziadzka, S.; Höhn, A.; Sievers, E.; Oldigs, H.D.; Schulz-Lell, G.; Schaub, J. Longitudinal manganese and copper balances in young infants and preterm infants fed on breast milk and adapted cow's milk formulas. Br. J. Nutr. 1989, 61, 559-572. [CrossRef] [PubMed]

65. Arnaud, J.; Favier, A. Copper, iron, manganese and zinc contents in human colostrum and transitory milk of French women. Sci. Total Environ. 1995, 159, 9-15. [CrossRef]

66. Cesar, A.; Marín, A.; Marin-Guirao, L.; Vita, R.; Lloret, J.; Del Valls, T.A. Integrative ecotoxicological assessment of sediment in Portmán Bay (southeast Spain). Ecotoxicol. Environ. Saf. 2009, 72, 1832-1841. [CrossRef] [PubMed]

67. Pérez-Sirvent, C.; García-Lorenzo, M.L.; Hernández-Pérez, C.; Martínez-Sánchez, M.J. Assessment of potentially toxic element contamination in soils from Portman Bay (SE, Spain). J. Soils Sediments 2018, 18, 2248-2258. [CrossRef]

68. Mandić, M.L.; Grgić, J.; Grgić, Z.; Seruga, M.; Hasenay, D. Aluminum levels in human milk. Sci. Total Environ. 1995, 170, 165-170. [CrossRef]

69. Nishijo, M.; Nakagawa, H.; Honda, R.; Tanebe, K.; Saito, S.; Teranishi, H.; Tawara, K. Effects of maternal exposure to cadmium on pregnancy outcome and breast milk. Occup. Environ. Med. 2002, 59, 394-397. [CrossRef]

70. García-Esquinas, E.; Pérez-Gómez, B.; Fernández, M.A.; Pérez-Meixeira, A.M.; Gil, E.; de Paz, C.; Iriso, A.; Sanz, J.C.; Astray, J.; Cisneros, M.; et al. Mercury, lead and cadmium in human milk in relation to diet, lifestyle habits and sociodemographic variables in Madrid (Spain). Chemosphere 2011, 85, 268-276. [CrossRef] [PubMed]

71. Mandour, R.A.; Ghanem, A.A.; El-Azab, S.M. Correlation between lead levels in drinking water and mothers' breast milk: Dakahlia, Egypt. Environ. Geochem. Health 2013, 35, 251-256. [CrossRef]

72. Satarug, S.; Ujjin, P.; Vanavanitkun, Y.; Baker, J.R.; Moore, M.R. Influence of body iron store status and cigarette smoking on cadmium body burden of healthy Thai women and men. Toxicol. Lett. 2004, 148, 177-185. [CrossRef] [PubMed]

73. Gundacker, C.; Pietschnig, B.; Wittmann, K.J.; Salzer, H.; Stöger, H.; Reimann-Dorninger, G.; Schuster, E.; Lischka, A. Smoking, cereal consumption, and supplementation affect cadmium content in breast milk. J. Expo. Sci. Environ. Epidemiol. 2007, 17, 39-46. [CrossRef]

74. Örün, E.; Yalçın, S.S.; Aykut, O.; Orhan, G.; Morgil, G.K.; Yurdakök, K.; Uzun, R. Breast milk lead and cadmium levels from suburban areas of Ankara. Sci. Total Environ. 2011, 409, 2467-2472. [CrossRef]

75. Chao, H.H.; Guo, C.H.; Huang, C.B.; Chen, P.C.; Li, H.C.; Hsiung, D.; Chou, Y. Arsenic, cadmium, lead, and aluminium concentrations in human milk at early stages of lactation. Pediatr. Neonatol. 2014, 55, 127-134. [CrossRef] [PubMed]

76. Ramírez, A. Toxicología del cadmio. Conceptos actuales para evaluar exposición ambiental u ocupacional con indicadores biológicos. An. Fac. Med. 2002, 63, 51-64. [CrossRef]

77. Arain, S.S.; Gul Kazi, T.; Afridi, H.I.; Brahman, K.D.; Eemuliah, N.; Shah, F.; Mughal, M.A. Arsenic content in smokeless tobacco products consumed by the population of Pakistan: Related health risk. J. AOAC Int. 2014, 97, 1662-1669. [CrossRef] [PubMed]

78. Turan, S.; Saygi, S.; Kiliç, Z.; Acar, O. Determination of heavy metal contents in human colostrum samples by electrothermal atomic absorption spectrophotometry. J. Trop Pediatr. 2001, 47, 81-85. [CrossRef] [PubMed]

79. Saha, K.K.; Engström, A.; Hamadani, J.D.; Tofail, F.; Rasmussen, K.M.; Vahter, M. Pre- and postnatal arsenic exposure and body size to 2 years of age: A cohort study in rural Bangladesh. Environ. Health Perspect. 2012, 120, 1208-1214. [CrossRef] [PubMed] 